Jurnal DISASTRI (Pendidikan Bahasa dan Sastra Indonesia)

Volume 3, Nomor 1, April 2021| P-ISSN : 2716-4114 | E-ISSN: 2722-3329

\title{
PROCESSES AND OBSTACLES IN LEARNING READING UNDERSTANDING USING THE KWLA STRATEGY
}

\author{
Yulianah Prihatin ${ }^{1}$

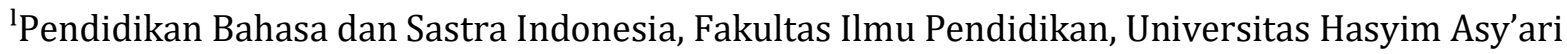 \\ Corresponding Author: ${ }^{1}$ yuliaana553@gmail.com
}

This study aims to determine the processes and obstacles in learning to read comprehension using the KWLA (Know, What, Learning, and Affect) strategy. The learning process goes through two cycles, namely cycle I and cycle II, while the intended obstacles are the obstacles experienced by lecturers, students and the environment during the learning process. This research approach uses qualitative descriptive methods. As for the object of research is learning or lecturing reading skills and the research subjects are students of third semester Indonesian Language and Literature Education, Faculty of Education, Hasyim Asy'ari University, totaling eighteen people, 13 girls and 5 boys. The resulting data will be analyzed. Data collection techniques used: survey techniques, recording techniques, observation techniques and note taking techniques. Data analysis techniques used data reduction techniques, data presentation, conclusing drawing / verification. The results showed that during the learning process the obstacles experienced by lecturers, students and the environment were reduced from cycles I and II.

Key words: Process, obstacles, reading understanding, KWLA Strategy

\section{PROSES DAN HAMBATAN DALAM PEMBELAJARAN MEMBACA PEMAHAMAN MELALUI STRATEGI KWLA}

\begin{abstract}
Abstrak
Penelitian ini bertujuan untuk mengetahui proses dan hambatan dalam pembelajaran membaca pemahaman menggunakan strategi KWLA (Know, What, Learning, and Affect). Proses pembelajaran melalui dua siklus, yaitu siklus I dan siklus II, sedangkan hambatan yang dimaksudkan adalah hambatan yang dialami dosen, mahasiswa dan lingkungan selama proses pembelajaran. Pendekatan penelitian ini menggunakan kualitatif dengan metode deskriptif. Adapun yang menjadi objek penelitian adalah pembelajaran atau perkuliahan keterampilan membaca dan subjek penelitiannya yaitu mahasiswa Pendidikan Bahasa dan Sastra Indonesia semester III, Fakultas Ilmu Pendidikan, Universitas Hasyim Asy'ari yang berjumlah delapan belas orang, 13 orang perempuan dan 5 orang laki-laki. Data yang dihasilkan akan dianalisis. Teknik pengumpulan data yang digunakan: tekik survey, teknik rekam, teknik simak dan teknik catat. Teknik analisis data menggunakan teknik reduksi data, penyajian data, conclusing drawing/verification. Hasil penelitian menunjukkan bahwa selama proses pembelajaran hambatan yang dialami oleh dosen, mahasiswa dan lingkungan semakin berkurang dari siklus I dan II.
\end{abstract}

Kata Kunci: Proses, hambatan, membaca pemahaman, srategi KWLA 
Jurnal DISASTRI (Pendidikan Bahasa dan Sastra Indonesia)

Volume 3, Nomor 1, April 2021| P-ISSN : 2716-4114 | E-ISSN: 2722-3329

\section{PENDAHULUAN}

Membaca merupakan aktivitas yang dilakukan untuk menemukan segala informasi maupun pengetahuan dalam isi bacaan. Membaca juga dapat diartikan sebagai proses memahami kata-kata yang terdapat pada isi bacaan sehingga pembaca mampu memahami isi teks yang dibacanya dan pada akhirnya dapat merangkum isi bacaan tersebut dengan menggunakan bahasa sendiri. Keterampilan membaca sudah sejak dini diajarkan kepada anak-anak melalui pendidikan sekolah dasar. Namun, kenyataan yang ada di masyarakat bahwa masalah minat baca sampai saat ini masih menjadi tema yang cukup aktual. Tema ini sering dijadikan topik pertemuan ilmiah dan diskusi oleh para pemerhati dan para pakar yang peduli terhadap perkembangan minat baca di Indonesia. Namun hasil dari pertemuan-pertemuan ilmiah tersebut belum memberikan suatu rekomendasi yang tepat bagi perkembangan yang signifikan terhadap minat baca masyarakat. Permasalahan yang dirasakan oleh bangsa Indonesia sampai saat ini adalah adanya data berdasarkan temuan penelitian dan pengamatan yang menunjukkan bahwa minat baca masyarakat Indonesia relatif masih sangat rendah.

Upaya menumbuhkan minat baca bukannya tidak dilakukan. Pemerintah melalui lembaga yang relevan telah mencanangkan program minat baca.Hanya saja yang dilakukan oleh pemerintah maupun institusi swasta untuk menumbuhkan minat baca belum optimal.Oleh karena itu, agar bangsa Indonesia dapat mengejar kemajuan yang telah dicapai oleh negara-negara tetangga, perlu menumbuhkan minat baca sejak dini. Sejak mereka mulai dapat membaca.Dengan menumbuhkan minat baca sejak anak-anak masih dini, diharapkan budaya membaca masyarakat Indonesia dapat ditingkatkan.

Oleh karena itu, keterampilan membaca di sekolah dasar harus ditangani dengan tepat karena pada dasarnya anak-anak cenderung lebih menyukai bacaan yang lebih menarik dari pada buku-buku pelajaran yang ada di sekolah. Namun, tidak hanya untuk peserta didik di sekolah dasar, melainkan juga pada mahasiswa di tingkat perguruan tinggi. Karena semakin canggihnya teknologi saat ini, menuntut masyarakat, yaitu salah satunya mahasiswa sebagai calon penerus generasi, untuk selalu memperbarui pengetahun dan harus memilih serta memilih informasi secara baik dengan meningkatkan ketrampilan membaca pemahamannya.

Pada dasarnya pendidik berperan utama dalam pembelajaran membaca pemahaman, keterampilan membaca pemahaman dapat tercapai jika pendidik memberikan proses pembelajaran yang menarik perhatian dan keaktifan peserta didik untuk memahami isi bacaan serta memberikan motivasi dan bimbingan pada peserta didik saat melaksanakan aktivitas membaca pemahaman. Dalam upaya meningkatkan keterampilan membaca peserta didik, pendidik perlu melaksanakan hal-hal tersebut. Strategi yang tepat pada kegiatan pembelajaran akan mempengaruhi pemahaman peserta didik pada kegiatan membaca. Aktivitas yang terjadi selama proses pembelajaran berlangsung adalah peserta didik mau membaca buku jika diminta oleh pendidik. Berbagai faktor yang bisa menjadi hambatan selama proses pembelajaran. Pada saat pembelajaran keterampilan membaca tidak menggunakan strategi yang sesuai dengan pembelajaran membaca pemahaman sehingga peserta didik merasa malas dalam kegiatan membaca. Untuk mengatasi kurangnya keterampilan membaca pemahaman maka diperlukan suatu strategu yang tepat dalam proses pembelajaran. Salah satu strategi yang efektif untuk diterapkan dalam pembelajaran keterampilan membaca pemahaman adalah dengan strategi KWLA (Know, What, Learn, and Affect).

Strategi ini menekankan pendidik untuk memperhatikan latar belakang dan pengetahuan siswa. Strategi $K-W-L-A$ merupakan strategi yang berbasis pada keaktifan siswa, siswa terlibat sebelum, saat, dan sesudah membaca. Strategi ini tidak hanya membantu siswa dalam 
memperoleh pengetahuan setelah membaca, tetapi juga memberikan kesempatan terhadap siswa untuk menghubungkan ketertarikan dan penilaian pribadi pada pengalaman belajar siswa. Siswa dapat melakukan curah pendapat sehingga guru mampu melihat seberapa besar ketertarikan dan pengetahuan siswa terkait teks bacaan (Wiesendanger, 2001: 99). Penelitian ini mengungkapkan tahapan proses pembelajaran membaca pemahaman menggunakan strategi KWLA dan hambatanhambatan yang dialami oleh dosen, mahasiswa dan lingkungan selama proses pembelajaran berlangung.

\section{LANDASAN TEORI}

\section{Membaca Pemahaman}

Membaca merupakan salah satu proses kejiwaan yang sangat rumit yang berlangsung pada diri pembaca. Pada dasarnya pembaca merekontruksi amanat atau isi yang tersurat dan yang tersirat dalam bacaan yang dihadapinya Menurut Nurgiyantoro (1995:224) membaca merupakan aktivitas mental untuk memahami apa yang dituturkan pihak lain melalui sarana tulisan. Syafi'ie (1994:6-7) menyebutkan hakikat membaca adalah: (a) Pengembangan keterampilan, mulai dari keterampilan memahami kata-kata, kalimat-kalimat, paragraf-paragraf dalam bacaan sampai dengan memahami secara kritis dan evaluatif keseluruhan isi bacaan. (b) Kegiatan visual, berupa serangkaian gerakan mata dalam mengikuti baris-baris tulisan, pemusatan penglihatan pada kata dan kelompok kata, melihat ulang kata dan kelompok kata untuk memperoleh pemahaman terhadap bacaan. (c) Kegiatan mengamati dan memahami kata-kata yang tertulis dan memberikan makna terhadap katakata tersebut berdasarkan pengetahuan dan pengalaman yang telah dipunyai. (d) Suatu proses berpikir yang terjadi melalui proses mempersepsi dan memahami informasi serta memberikan makna terhadap bacaan. (e) Proses mengolah informasi oleh pembaca dengan menggunakan informasi dalam bacaan dan pengetahuan serta pengalaman yang telah dipunyai sebelumnya yang relevan dengan informasi tersebut. (f) Proses menghubungkan tulisan dengan bunyinya sesuai dengan sistem tulisan yang digunakan. (g) Kemampuan mengantisipasi makna terhadap baris-baris dalam tulisan. Kegiatan membaca bukan hanya kegiatan mekanis saja, melainkan merupakan kegiatan menangkap maksud dari kelompok-kelompok kata yang membawa makna.

Menurut Tarigan (2008: 1113) ditinjau dari segi terdengar atau tidaknya suara pembaca waktu melakukan kegiatan membaca, maka dapat dibagi menjadi membaca nyaring dan membaca dalam hati.

a. Membaca nyaring (bersuara)

Membaca nyaring adalah suatu aktifitas atau kegiatan yang merupakan alat bagi guru, murid ataupun pembaca bersama-sama dengan orang lain atau

pendengar untuk menangkap atau memahami informasi, pikiran, dan perasaan

seorang pengarang (Tarigan, 1982: 23). Pada kegiatan belajar berbahasa, kegiatan membaca nyaring sangat besar kontribusinya terhadap belajar berbicara. Melalui membaca nyaring siswa belajar mengucapkan bunyi-bunyi bahasa yang dipelajarinya secara benar. Bahkan, siswa secara tidak langsung mengucapkan dengan benar kelompok kata, kalimat, dan 
wacana utuh melalui membaca bersuara.

b. Membaca Senyap (Dalam Hati) Membaca senyap atau dalam hati adalah membaca tidak bersuara, tanpa gerakan bibir, tanpa gerakan kepala, tanpa berbisik, memahami bahan bacaan yang dibaca secara diam atau dalam hati, kecepatan mata dalam membaca tiga kata per detik, menikmati bahan bacaan yang dibaca dalam hati, dan dapat menyesuaikan kecepatan membaca dengan tingkat kesukaran yang terdapat dalam bahan bacaan itu. Dalam membaca senyap pembaca hanya mepergunakan ingatan visual yang melibatkan pengaktifan mata dan ingatan.

Sehubungan membaca dalam hati, menurut Tarigan (1997:30-31) dan Harras (1995: 5) berpendapat bahwa dilihat dari cakupan bahan bacaan yang dibaca, secara garis besar kita dapat membedakannya atas dua jenis kegiatan membaca, yaitu membaca ekstensif dan membaca intensif. Membaca ekstensif diantaranya yaitu membaca survey, sekilas dan dangkal, sedangkan membaca intensif yaitu membaca teliti, pemahaman, kritis, ide dan kreatif. Dalam penelitian ini, lebih menitikberatkan pada membaca pemahaman.

Tujuan membaca pemahaman yaitu:

a. Menikmati keindahan yang terkandung dalam bacaan.

b. Membaca bersuara untuk memberikan kesempatan kepada seseorang menikmati teks bacaan. c. Menggunakan strategi tertentu untuk memahami teks bacaan

d. Menggali simpanan pengetahuan atau schemata seseorang tentang suatu topik.

e. Menghubungkan pengetahuan baru dengan schemata seseorang.

f. Mencari informasi untuk penyusunan suatu bacaan atau laporan.

g. Memberikan kesepatan kepada seseorang melakukan eksperimentasi untuk meneliti sesuatu yang dipaparkan dalam suatu teks bacaan.

h. Menjawab pertanyaan dikemukakan dalam teks bacaan.

Tampubolon menyatakan bahwa membaca pemahaman merupakan suatu kegiatan membaca untuk membina daya nalar. Membaca dalam pembinaan daya nalar merupakan kegiatan membaca yang dilakukan seseorang untuk memahami suatu makna yang tersirat pada hal tertulis, maka sebab itu untuk memahami suatu makna seseorang harus melatih daya nalar agar dapat menangkap makna yang tersirat pada hal tertulis. Secara umum kata pemahaman diartikan sebagai upaya memahami atau mengerti isi dan makna dari suatu wacana baik berbentuk lisan maupun tulisan. Memahami wacana tulis berarti usaha seseorang dalam memahami atau mengerti isi suatu wacana yang disajikan dalam bentuk tulisan, yang dalam kegiatan berbahasa disebut membaca, sedangkan memahami wacana lisan berarti upaya seseorang dalam memahami atau 
mengerti isi dari wacana yang disajikan dalam bentuk lisan, yang dalam kegiatan berbahasa dinamakan menyimak.

\section{Strategi KWLA}

Strategi $\quad K-W-L-A \quad$ (What I Already Know, What I Want to Know, What I Learned, and The Affect of the Story) merupakan salah satu strategi membaca.

Strategi $\quad K$ - $W$ - $L-A \quad$ menekankan pengajar untuk memperhatikan latar belakang dan pengetahuan siswa. Strategi $K-W-L-A$ merupakan strategi yang berbasis pada

keaktifan siswa, siswa terlibat sebelum, saat, dan sesudah membaca. Strategi ini tidak hanya membantu siswa dalam memperoleh pengetahuan setelah membaca,

tetapi juga memberikan kesempatan terhadap siswa untuk menghubungkan

ketertarikan dan penilaian pribadi pada pengalaman belajar siswa. Siswa dapat

melakukan curah pendapat sehingga guru mampu melihat seberapa besar ketertarikan dan pengetahuan siswa terkait teks bacaan (Wiesendanger, 2001: 99).

1. Membuat tabel dengan empat kolom seperti berikut:

\begin{tabular}{|l|l|l|l|}
\hline $\begin{array}{l}\text { Apa yg } \\
\text { saya } \\
\text { ketahui }\end{array}$ & $\begin{array}{l}\text { Apa yg } \\
\text { ingin } \\
\text { saya } \\
\text { ketahui }\end{array}$ & $\begin{array}{l}\text { Apa } \\
\text { yang } \\
\text { saya } \\
\text { pelajari }\end{array}$ & $\begin{array}{l}\text { Pengaruh } \\
\text { Cerita }\end{array}$ \\
\hline & & & \\
\hline
\end{tabular}

2. Bertanya kepada siswa apa yang telah mereka ketahui untuk tentang topik yang akan dibaca. Tulislah informasi itu pada kolom pertama.

3. Bertanya kepada siswa pertanyaan apa yang akan mereka jawab tentang topik yang akan dibaca. Tulis pertanyaan ini dalam kolom dua.

4. Setelah membaca, mintalah siswa untuk menjawab pertanyaan dan informasi lainnya dalam kolom tiga.

5. Gunakan kolom empat untuk menulis jawaban pertanyaan pertama yang berpengaruh. Salah satu contoh pertanyaan: "apa yang membuat saya tertarik." Siswa secara reflek memiliki informasi penting oleh jawaban dalam pertanyaan: "mengapa informasi ini penting untuk saya dan bagaimana membantu saya mengetahui informasi tersebut."

6. Jelaskan kepada siswa jika mereka juga dapat menggunakan kolom keempat untuk merespon dengan sikap yang baru tentang pembelajaran mereka. Contohnya siswa mungkin mencatat tentang jangkrik dan serangga lainnya mendapatkan tempat yang baik dalam budaya Asia.

7. Adalah sangat penting untuk melakukan diskusi. Jika guru meminta siswa untuk mendengarkan respon teman sebayanya, dan berbicara tentang respon sendiri, dan kemudian respon tertulis mereka kualitasnya akan lebih baik (Wiesendanger,2001). 
Jurnal DISASTRI (Pendidikan Bahasa dan Sastra Indonesia)

Volume 3, Nomor 1, April 2021| P-ISSN : 2716-4114 | E-ISSN: 2722-3329

\section{PEMBAHASAN}

A. Proses Pembelajaran Membaca Pemahaman Teks Naratif dengan Strategi KWLA

SIKLUS I

a. Tahap Perencanaan

1) Menyusun dan membuat RPS (Rencana Pembelajaran Semester),

2) Merancang skenario pembelajaran dengan sebaikbaiknya,

3) Menyusun dan membuat lembar observasi, angket, dan lembar evaluasi.

\section{b. Tahap Pelaksanaan}

Pada tahap pelaksanaan dilakukan pada hari Rabu tanggal 12 September 2018 di ruang 2.09 dengan jumlah 2 SKS dengan alokasi waktu 2 x 50 menit atau 100 menit, dimulai pukul 08.00-09.40 WIB. Adapun kegiatan pada tahap pelaksanaan ini yaitu:

\section{1) Kegiatan Awal}

Pada kegiatan awal, alokasi waktu yang digunakan kurang lebih 15 menit. Beberapa kegiatan yang dilakukan yaitu:

a) Mengawali perkuliahan dengan berdoa dan mengecek presensi mahasiswa.

b) Dosen melakukan tanya jawab dengan mahasiswa tentang materi yang diberikan pada pertemuan sebelumnya.

c) Dosen menjelaskan kompetensi yang akan dicapai.

d) Dosen melakukan pretest dengan cara memberikan pertanyaan untuk memancing pengetahuan mahasiswa tentang materi yang akan disampaikan.
2) Kegiatan Inti

Pada kegiatan inti, alokasi waktu yang digunakan yaitu 60 menit. Berikut ini kegiatan inti yang dilakukan pada saat menggunakan strategi KWLA.

a) Dosen menjelaskan materi tentang membaca pemahaman dengan memanfaatkan media power point.

b) Selama menjelaskan, dosen memberikan kesempatan pada mahasiswa untuk aktif bertanya sekaligus dosen juga melakukan penilaian proses.

c) Setelah menjelaskan, dosen membimbing mahasiswa membuat tabel sesuai dengan arahan dosen yang akan digunakan sebagai lembar panduan membaca pemahaman teks naratif dengan strategi KWLA.

d) Dosen memberikan kesempatan pada siswa untuk membuka laptop, notebook atau ponsel pintar untuk mencari teks naratif dengan memanfaatkan fasilitas jaringan wifi yang sudah diberikan oleh universitas.

e) Setelah mahasiswa siap dengan teks naratif, dosen menjelaskan aturan pembelajaran dengan strategi KWLA.

f) Setelah mahasiswa memahami aturan pembelajaran, dosen mengajukan pertanyaan tentang "apa yang telah mereka ketahui tentang topik yang akan dibaca". Jawaban dituliskan pada kolom pertama pada tabel.

g) Jika sudah selesai mengisi kolom pertama, maka dosen 
lanjut bertanya tentang "apa yang ingin mereka ketahui pada topik yang mereka baca". Jawaban dituliskan pada kolom kedua.

h) Setelah selesai membaca, mahasiswa harus menjawab pertanyaan dan informasi lainnya dalam kolom tiga.

i) Jika kolom ketiga sudah terisi, mahasiswa harus mengisi kolom keempat. kolom keempat diisi sesuai apa yang didapatkan mahasiswa selama membaca teks yang ditemukan dan pengaruhnya apa terhadap pengetahuan mahasiswa. Misalnya "alasan mengapa informasi yang dibaca itu penting" atau pesan apa yang didapat setelah membaca teks.

j) Setelah kolom sudah terisi semua, maka dosen membuat 4 kelompok besar, yang masing-masing kelompok terdiri dari lima mahasiswa. Masing-masing mahasiswa menyampaikan hasil pemikirannya yang tertuang dalam tabel dan melakukan diskusi serta saling merespon dari satu kelompok.

\section{3) Kegiatan Penutup}

Pada kegiatan penutup, alokasi waktu yang digunakan kurang lebih 15 menit, adapun beberapa kegiatan yang dilakukan yaitu:

a) Dosen merefleksi dan menanyakan kesulitan yang dihadapi oleh mahasiswa dalam pembelajaran membaca pemahaman teks naratif.

b) Dosen melakukan postest dengan cara memberikan tanya jawab tentang materi membaca pemahaman.

c) Dosen menyimpulkan materi yang sudah disampaiakan.

d) Doa dan salam

\section{SIKLUS II}

a. Tahap Perencanaan Ulang

a) Menyempurnakan dan memperbaiki RPS, sehingga kekurangan pada siklus I dapat diperbaiki.

b) Merancang skenario pembelajaran dengan sebaik-baiknya;

c) Menyusun dan membuat lembar observasi, angket, dan lembar evaluasi.

\section{b. Tahap Pelaksanaan}

Pada tahap pelaksanaan dilakukan pada hari Rabu tanggal 17 September 2018 di ruang 2.09 dengan jumlah 2 SKS dengan alokasi waktu $2 \mathrm{x}$ 50 menit atau 100 menit, dimulai pukul 08.00-09.40 WIB. Adapun kegiatan pada tahap pelaksanaan ini yaitu:

\section{1) Kegiatan Awal}

Pada kegiatan awal, alokasi waktu yang digunakan kurang lebih 15 menit. Beberapa kegiatan yang dilakukan yaitu:

a) Mengawali perkuliahan dengan berdoa dan mengecek presensi mahasiswa.

b) Dosen melakukan tanya jawab dengan mahasiswa tentang materi yang diberikan pada pertemuan sebelumnya.

c) Dosen melakukan pretest dengan cara memberikan pertanyaan untuk memancing pengetahuan mahasiswa tentang materi yang akan disampaikan.

2) Kegiatan Inti Pada kegiatan inti, 
alokasi waktu yang digunakan yaitu 60 menit. Berikut ini kegiatan inti yang dilakukan pada saat menggunakan strategi KWLA.

a) Dosen menjelaskan materi tentang membaca pemahaman dan teks naratif menggunakan media power point.

b) Selama menjelaskan, dosen memberikan kesempatan pada mahasiswa untuk aktif bertanya sekaligus dosen juga melakukan penilaian proses.

c) Setelah menjelaskan, dosen membimbing mahasiswa membuat tabel seperti pertemuan sebelumnya

d) Dosen memberikan teks naratif yang sudah disiapkan sebelumnya kepada mahasiswa.

e) Setelah mahasiswa siap dengan teks naratif, dosen menjelaskan aturan pembelajaran.

f) Setelah mahasiswa memahami aturan pembelajaran, dosen mengajukan pertanyaan tentang "apa yang telah mereka ketahui tentang topik yang akan dibaca". Jawaban dituliskan pada kolom pertama pada tabel.

g) Jika sudah selesai mengisi kolom pertama, maka dosen lanjut bertanya tentang "apa yang ingin mereka ketahui pada topik yang mereka baca". Jawaban dituliskan pada kolomkedua.

h) Setelah selesai membaca, mahasiswa harus menjawab pertanyaan dan informasi lainnya dalam kolom tiga.

i) Jika kolom ketiga sudah terisi, mahasiswa harus mengisi kolom keempat. kolom keempat diisi sesuai apa yang didapatkan mahasiswa selama membaca teks yang ditemukan dan pengaruhnya apa terhadap pengetahuan mahasiswa. Misalnya "alasan mengapa informasi yang dibaca itu penting" atau pesan apa yang didapat setelah membaca teks.

j) Setelah kolom sudah terisi semua, maka dosen membuat 4 kelompok besar, yang masing-masing kelompok terdiri dari lima mahasiswa. Masing-masing mahasiswa menyampaikan hasil pemikirannya yang tertuang dalam tabel dan melakukan diskusi serta saling merespon dari satu kelompok

\section{3) Kegiatan Penutup}

Pada kegiatan penutup, alokasi waktu yang digunakan kurang lebih 15 menit, adapun beberapa kegiatan yang dilakukan yaitu:

a) Dosen merefleksi dan menanyakan kesulitan yang dihadapi oleh mahasiswa dalam pembelajaran membaca pemahaman teks naratif menggunakan strategi KWLA

b) Dosen melakukan postest dengan cara memberikan tugas individu terakit dengan membaca pemahaman.

c) Dosen dan mahasiswa menyimpulkan materi yang sudah dipelajari.

d) Doa dan salam 


\section{B. Hambatan Proses \\ Pembalajaran Membaca \\ Pemahaman Menggunakan \\ Strategi KWLA}

Setiap

proses

pembelajaran tentu mengalami

hambatan atau kendala.

Hambatan dialami oleh semua

komponen yang terlibat dalam

proses pembelajaran yaitu dosen sebagai pendidik, mahasiswa sebagai peserta didik dan lingkungan sebagai sarana pendidikan. Setiap siklus memiliki hambatan yang berbeda. Pada siklus I, penerapan strategi KWLA memiliki hambatan yang lebih banyak, sedangkan pada siklus II hambatan bisa diminimalisir karena sudah dilakukan perencanaan ulang sesuai dengan hasil refleksi pada siklus I.

1. Hambatan pada Siklus I

a. Dosen

1) Terlalu cepat dalam menjelaskan materi dan alur pembelajaran. Pada siklus I, hambatan yang dialami dosen adalah belum bisa mengontrol tempo saat menjelaskan, sehingga terlalu cepat ketika menjelaskan. Hal ini mempengaruhi

pemahaman mahasiswa terkait dengan materi yang disampaikan dosen. Sehingga mahasiswa sering interupsi ke dosen untuk mengulang penjelasan karena mahasiswa belum memahami.

b. Mahasiswa

1) Banyaknya mahasiswa yang terlambat dan tidak disiplin waktu. Keterlambatan mahasiswa dikarenakan beberapa alas an diantaranya yaitu, jarak rumah dengan kampus yang jauh, tidak bisa bangun pagi dan tidak ada kendaraan.

2) Masih ada mahasiswa yang kurang semangat dalam perkuliahan. Kurang semangatny mahasiswa dikarenakan ada beberapa yang masih merasa mengantuk karena kuliah di waktu pagi.

3) Masih ada mahasiswa yang kurang aktif dalam pembelajaran.

Ketidakaktifan mahasiswa dikarenakan mahasiswa masih belum percaya diri untuk mengajukan pertanyaan atau menjawab pertanyaan dari dosen.

4) Mahasiswa kurang bertanggung jawab saat diberikan tugas individu. Beberapa mahasiswa masih ada yang awalnya mengabaikan tugas yang diberikan oleh dosen, sehingga dosen perlu memantau mahasiswa tersebut.

5) Banyaknya mahasiswa yang kurang memperhatikan kaidah Bahasa Indonesia saat mengerjakan tugas secara tertulis. Pada poin ini, mahasiswa masih banyak melakukan kesalahan ejaan dalam menuliskan tugas individu pada tabel yang sudah dibuat. Masih banyak mahasiswa yang mengabaikan ejaan. Sehingga ketelitian menggunakan ejaan dimasukkan dalam criteria penilaian. 
c. Lingkungan

1) Jaringan wifi yang terkendala.

2) Pada pembelajaran siklus I, memerlukan jaringan wifi untuk mencari teks naratif, ketika wifi mengalami kendala, maka pembelajaran juga mengalami gangguan. Salah satu solusi yang diberikan dosen saat wifi tidak bisa diakses adalah mahasiswa menggunakan jaringan data masingmasing.

3) Suasana bising dan ramai di luar kelas, sehinga membuat mahasiswa yang di dalam kelas merasa terganggu saat perkuliahan.

4) Hal ini dikarenakan di sekitar gedung perkuliahan sedang ada perbaikan fasilitas, sehingga suara yang ditimbulkan oleh alatalat renovasi cukup mengganggu untuk proses pembelajaran keterampilan membaca.

5) Ruang kelas yang terasa panas. Hal ini dirasakan ketika 20 menit sebelum perkuliahan berakhir.

2. Hambatan pada Siklus II

a. Dosen

1) Masih sedikit terlalu cepat saat menjelaskan namun sudah lebih baik dari pertemuan selanjutnya. Pada siklus II, dosen sudah bisa mengontrol penjelasannya sehingga tidak terlalu cepat.

b. Mahasiswa

1) Masih ada mahasiswa yang kurang aktif dalam pembelajaran.

2) Masih ada mahasiswa yang kurang memperhatikan kaidah Bahasa Indonesia saat mengerjakan tugas secara tertulis.

c. Lingkungan

1) Suasana bising dan ramai di luar kelas, sehinga membuat mahasiswa yang di dalam kelas merasa terganggu saat perkuliahan.

\section{SIMPULAN}

Berdasarkan hasil penelitian didapatkan hasil bahwa: 1) proses pembelajaran membaca pemahaman menggunakan strategi KWLA antara siklus I dan siklus II adalah sama untuk setiap tahapan, namun yang membedakan hanya pada siklus II pada bagian perencanaan dibuat sebagai perencanaan ulang. Perencanaan ulang didasarkan pada hasil evaluasi pada siklus I, sehingga pada siklus II dapat lebih baik lagi. 2) Hambatan pada setiap siklus mengalamai perbedaan. Pada siklus II, hambatan yang dialami oleh dosen, mahasiswa dan lingkungan masih banyak, namun pada siklus II, hambatan bisa diminimalisir. Hanya beberapa hambatan yang memang tidak bisa diselesaikan secara langsung, misalnya hambatan lingkungan yaitu suara bising yang berasal dari luar kelas.

\section{DAFTAR PUSTAKA}

Harras K.A. (1995). Membaca Minat Baca Masyarakat Kita dalam jurnal Mimbar Bahasa dan Seni No.XXII 1995.

Nurgiyantoro, Burhan. 1995. Penelitian dalam Pengajaran Bahasa dan Sastra. Yogyakarta: BPFE.

Syafi'ie, Imam. 1999. Pengajaran Membaca Terpadu. Bahan Kursus Pendalaman Materi Guru Inti PKG Bahasa dan Sastra Indonesia. Malang: IKIP.

Tampubolon, DP. 1987. Kemampuan Membaca: Teknik Membaca Efektif dan Efisien 
Jurnal DISASTRI (Pendidikan Bahasa dan Sastra Indonesia)

Volume 3, Nomor 1, April 2021| P-ISSN : 2716-4114 | E-ISSN: 2722-3329

Bandung: Angkasa.

Tarigan, D. 1997. Kependidikan

Keterampilan Berbahasa. Jakarta: Modul Universitas Terbuka

Tarigan, H.G. 2008. Membaca Sebagai Suatu Keterampilan Berbahasa. Bandung:
Angkasa

Wiesendanger, D., Katherine. 2001. Strategies for Literacy Education. Columbus. Ohio: Merril Prentice Hall. 